\title{
大腿中央前面筋厚・脂肪厚，大腿周径，大腿前面筋硬度測定の
}

\author{
再現性および膝伸展筋力との関連
}

\section{Associations among the reproducibility of anterior central femoral muscle/fat thickness, femoral circumference, and anterior femoral muscle hardness measurement and knee extension muscle strength}

\author{
小林 佐季 ${ }^{1}$, 质若あかり ${ }^{1)}$, 野中 紘士 ${ }^{11}$, 安彦 鉄平 $^{11}$ \\ 白岩加代子 ${ }^{1)}$, 堀江 淳 ${ }^{1)}$, 村田 伸 ${ }^{1)}$ \\ Saki Kobayashi ${ }^{1)}$, Akari Torawaka ${ }^{1)}$ Koji Nonaka ${ }^{1)}$, Teppei Abiko ${ }^{1)}$ \\ Kayoko Shiraiwa $^{1)}$, Jun Horie ${ }^{1)}$, Shin Murata ${ }^{1)}$ \\ 要旨：本研究は, 大腿中央前面筋厚 (以下, 筋厚) - 脂肪厚 (以下, 脂肪厚), 大腿周径, \\ 大腿前面筋硬度（以下，筋硬度）測定の検者内・検者間再現性と膝伸展筋力との関連を検 \\ 討した。対象は, 健常成人 20 名（平均年齢：男性 $20.1 \pm 0.3$ 歳，女性 $20.2 \pm 0.4$ 歳）の両下 \\ 肢計 40 脚であり, 筋厚, 大腿周径, 筋硬度を各 2 回ずつ測定し級内相関係数を求め, 検者 \\ 内・検者間での再現性を検討した。また，膝伸展筋力と各項目との相関をPearson の積 \\ 率相関係数を求めて検討した。その結果, 筋厚, 脂肪厚, 大腿周径の再現性は, 男女とも \\ に級内相関係数が 0.9 以上と極めて高かったが，筋硬度は検者間で男性が 0.763 , 女性が \\ 0.787 と低い值を示した。筋力との相関では, 男性の大腿周径のみに有意な相関 $(\mathrm{r}=0.54$, \\ $\mathrm{p}<0.05$ ）が認められた。これらの結果から，筋硬度の測定は測定值の再現性に留意する \\ こと，また男性の大腿周径は膝伸展筋力を反映するが，女性の大腿周径の測定值は脂肪厚 \\ の影響を考慮する必要性が示唆された。 \\ キーワード : 筋厚, 大腿周径, 筋硬度, 再現性, 膝伸展筋力

\begin{abstract}
In this study, we examined the associations among the intra-/inter-examiner reproducibility of anterior central femoral muscle thickness (muscle thickness), femoral circumference, and anterior femoral muscle hardness (muscle hardness) measurement and knee extension muscle strength. The subjects were 20 healthy adults (mean age; male 20.1 \pm 0.3 years, female $20.2 \pm 0.4$ years, total: 40 bilateral lower limbs). The muscle thickness, femoral circumference, and muscle hardness were measured twice, respectively, and the interclass correlation coefficient was calculated to investigate the intra-/inter-examiner reproducibility. Furthermore, the correlation between the knee extension muscle strength and each item was examined by calculating Pearson's correlation coefficient. The interclass correlation coefficients of the reproducibility of the muscle thickness, fat thickness, and femoral circumference were $\geq 0.9$ regardless of sex, but the inter-examiner correlation coefficients of the muscle hardness in males and females were 0.763 and 0.787 , respectively. Only the femoral circumference in males was correlated with the muscle strength $(\mathrm{r}=0.54$, $\mathrm{p}<0.05$ ). These results suggest that the reproducibility of data should be considered for muscle hardness measurement, and that the influence of fat thickness on the femoral circumference in females must be considered, although the femoral circumference in males reflects the knee extension muscle strength.
\end{abstract}

Key words: muscle thickness, femoral circumference, muscle hardness, reproducibility, knee extension muscle strength.

受付日：2018年 5 月 1 日，採択日：2018年 6 月12日

京都橘大学健康科学部理学療法学科：=607-8175 京都府京都市山科区大宅山田町34 TEL : 075-571-1111

Email:murata-s@tachibana-u.ac.jp

Department of Physical Therapy, Faculty of Health Sciences, Kyoto Tachibana University

34 Oyakeyamada-cho, Yamashina-ku, Kyoto, 607-8175, Japan 


\section{I 、はじめに}

下肢の重要な機能は，身体を支える支持機能と身体 を移動させる移動機能である ${ }^{1,2)}$ 。下肢機能は，筋力を 中心に分析され，なかでも大腿四頭筋が下肢機能を最 も反映する筋であるとされ ${ }^{12}$ ，高齢者の歩行能力 ${ }^{3.4)}$, 動的バランス能力, 生活機能の維持 - 向上 ${ }^{5)}$ との関連 が報告されている。したがって，大腿四頭筋を客観的 かつ多面的に評価することは重要である。

先行研究では, 筋力と関連する因子として筋厚, 四 肢周径, 筋硬度などが報告されている 中央前面筋厚は，大腿四頭筋筋力と強い正の相関が認 められたことが報告されている6)。また，四肢周径測 定は筋萎縮の有無・程度, 筋線維の発達状態を反映す るものとされ7)，筋力との相関も認められている ${ }^{6}$ 。さ らに,筋力が高い者は筋硬度も高いと報告されており ${ }^{8)}$, 筋硬度も筋力と関係している可能性がある。

しかし，これらの測定値の再現性については問題が 指摘されている。超音波画像装置は，プローブを操作 する者の技術により測定值が変化すること ${ }^{9}$, 四肢周 径はランドマークの誤認により同一検者内の測定值に も差が生じてしまうこと ${ }^{10}$ などが指摘されている。筋 硬度もまた，検者間の再現性に一貫性がないとされて いる ${ }^{11,12)}$ 。

骨格筋を正確に評価するには，検者内および検者間 で測定值の再現性が不可欠である。さらに，筋厚，周 径, 筋硬度測定の再現性を検者内と検者間の両方で検 討したうえで，これら 3 つの因子と筋力との関連を報 告している研究は見当たらない。そこで本研究では, 検者内と検者間の大腿中央前面筋（大腿直筋 + 中間広 筋）の筋厚（以下，筋厚)，大腿周径，大腿前面筋硬 度 (以下, 筋硬度) 測定の再現性を級内相関係数で検 討し, 最大膝伸展筋力との相関について検討した。ま た，大腿の脂肪量は大腿周径との相関が認められてお $り^{13)}$ ，脂肪量は脂肪厚に反映される ${ }^{14)}$ ことから，大腿 中央前面脂肪厚（以下，脂肪厚）も大腿周径に影響を 及ぼすと考えられる。そのため, 同様に再現性および 最大膝伸展筋力との相関について検討した。

\section{II. 対象と方法}

\section{1. 対 象}

健常成人 20 名（男性10名, 女性10名）の両下肢40脚 を対象とした。対象者の平均年齢は男性 $20.1 \pm 0.3$ 歳, 女性 $20.2 \pm 0.4$ 歳, 平均身長は男性 $174.5 \pm 4.4 \mathrm{~cm}$, 女 性 $157.5 \pm 5.0 \mathrm{~cm}$ ，平均体重は男性 $65.3 \pm 6.7 \mathrm{~kg}$ ，女性
49. $5 \pm 3.3 \mathrm{~kg}$ であった。対象者には研究の趣旨と内容, 得られたデー夕は研究の目的以外には使用しないこと, および個人情報の漏洩に注意することについて説明し， 理解を得たうえで協力を求めた。また，研究への参加 は自由意思であることを口頭で説明し，同意を得た上 で研究を開始した。

\section{2. 方 法}

筋厚, 脂肪厚, 大腿周径, 筋硬度と最大膝伸展筋力 （以下，膝伸展筋力）を測定した。筋厚，脂肪厚，大 腿周径，筋硬度の測定は大学の理学療法学科に所属す る 3 年生の検者 2 名が, 1 検者につき連続して 2 回ず つ行った。本研究の測定は2017年 6 月の午前11時から 午後 2 時の間に行った。

対象者には治療用ベッド中央に背臥位で膝関節伸展 位にて筋収縮が生じないよう安静にするように指示し， 筋厚, 脂肪厚, 大腿周径, 筋硬度は, 上前腸骨棘と膝 蓋骨上縁中央を結んだ中点をマーキングし測定した99 筋厚，脂肪厚の測定にはプローブの押圧を測定可能な パーソナル・デジタル超音波画像装置（ビューズ・ア イ，酒井医療株式会社製）を使用した。測定モードは

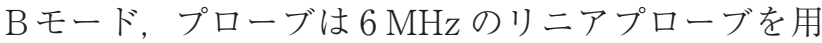
いた。プローブの押圧は $100 \pm 5 \mathrm{gf}$ とした。画像の解 析は，超音波画像装置に付属のソフトを用いて行った。 大腿周径は，市販のメジャーを使用し，ミリ単位まで 測定した。筋硬度測定には，筋硬度計（NEWTONE TDM-Z1(RB)，TRY-ALL 社製)を使用し，練習を行っ た後，測定を開始した。

膝伸展筋力の測定には，ハンドヘルドダイナモメー 夕（ $\mu$ Tas F-1,アニマ社製）を使用した。被検者には， 端座位にて膝関節 $90^{\circ}$ 屈曲位で，体幹を垂直位に保つ ように指示し，膝伸展筋力を測定した。ハンドヘルド ダイナモメータのセンサーパッドは下腿遠位部前面に 設置し，後方の検查台支柱にベルトで固定した。測定 中はセンサーパッドのずれを防止するため，検者が前 方で軽く支持した。また，膝窩部の圧迫による疼痛を 回避するために，同部位にバスタオルを敷いた ${ }^{15)}$ 。な お，この方法による膝伸展筋力測定は再現性が高いこ とが確認されている ${ }^{15)}$

統計処理として, 筋厚, 脂肪厚, 大腿周径, 筋硬度 の測定值を級内相関係数（Intraclass correlation coefficinent; ICC) を求め, 同一検者内，複数検者間での 再現性を検討した。

ICC による reliability 值の評価基準は，先行研究に 
準じて0.6未満で「要再考」, 0.6 以上で「可能」, 0.7 以上で「普通」, 0.8 以上で「良好」, 0.9 以上で「優秀」, 完全な一致では 1 とした ${ }^{16)}$ 。また, 筋厚, 脂肪厚, 大 腿周径, 筋硬度測定值の平均と膝伸展筋力の測定值を, Pearsonの積率相関係数を求めて検討した。相関係数

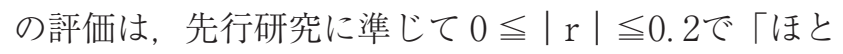

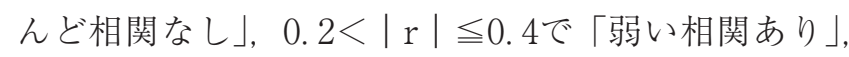
$0.4<|\mathrm{r}| \leqq 0.7 て ゙ 「$ 比較的強い相関あり」, $0.7<\mid \mathrm{r}$ $\mid \leqq 1.0$ で「強い相関あり」とした17)。解析は SPSS Statistics Version 22.0を用い，有意水準は $5 \%$ とした。

\section{III. 結 果}

筋厚および脂肪厚, 大腿周径, 筋硬度測定の検者内 再現性を表 1 , 検者間再現性を表 2 に示す。筋厚, 脂 肪厚, 大腿周径は男女ともに検者内で $\operatorname{ICC}(1,1)=0.98$ 以上，検者間で $\operatorname{ICC}(2,1)=0.93$ 以上，筋硬度は男女 ともに検者 $\mathrm{A}$ では $\operatorname{ICC}(1,1)=0.955 \sim 0.979$, 検者 B で は $\operatorname{ICC}(1,1)=0.796 \sim 0.885$, 検者間で $\operatorname{ICC}(2,1)=$ 0.76〜0.79であった。

筋厚および脂肪厚, 大腿周径, 筋硬度測定と膝伸展 筋力の相関について表 3 に示す。膝伸展筋力と有意な

表 1 測定值の検者内再現性

\begin{tabular}{|c|c|c|c|c|c|c|}
\hline & & & 1 回目 & 2 回目 & $\operatorname{ICC}(1,1)$ & $95 \% \mathrm{CI}$ \\
\hline \multicolumn{7}{|l|}{ 男性 } \\
\hline & \multirow[t]{2}{*}{ 筋厚 (mm) } & 検者 A & $34.7 \pm 4.4$ & $34.4 \pm 4.2$ & 0.979 & $0.948-0.992$ \\
\hline & & 検者 B & $35.1 \pm 4.5$ & $34.6 \pm 4.8$ & 0.982 & $0.953-0.993$ \\
\hline & \multirow[t]{2}{*}{ 脂肪厚 (mm) } & 検者 A & $6.5 \pm 2.7$ & $6.5 \pm 2.6$ & 0.989 & $0.973-0.996$ \\
\hline & & 検者 B & $6.5 \pm 2.7$ & $6.4 \pm 2.7$ & 0.989 & $0.974-0.996$ \\
\hline & \multirow[t]{2}{*}{ 大腿周径 $(\mathrm{cm})$} & 検者 A & $54.1 \pm 4.2$ & $54.1 \pm 4.2$ & 1. 000 & $1.000-1.000$ \\
\hline & & 検者 B & $54.1 \pm 4.1$ & $54.1 \pm 4.1$ & 1. 000 & $0.999-1.000$ \\
\hline & \multirow[t]{2}{*}{ 筋硬度 } & 検者 A & $21.2 \pm 3.4$ & $20.7 \pm 3.1$ & 0.955 & $0.887-0.982$ \\
\hline & & 検者 B & $20.7 \pm 3.2$ & $19.8 \pm 2.6$ & 0.796 & $0.498-0.919$ \\
\hline \multicolumn{7}{|l|}{ 女性 } \\
\hline & \multirow[t]{2}{*}{ 筋厚 (mm) } & 検者 A & $30.3 \pm 4.6$ & $30.4 \pm 4.0$ & 0.988 & $0.971-0.995$ \\
\hline & & 検者 B & $30.2 \pm 4.4$ & $29.9 \pm 4.6$ & 0.990 & $0.975-0.996$ \\
\hline & \multirow[t]{2}{*}{ 脂肪厚 $(\mathrm{mm})$} & 検者 A & $9.8 \pm 2.1$ & $10.0 \pm 2.1$ & 0.984 & $0.958-0.994$ \\
\hline & & 検者 B & $9.9 \pm 2.1$ & $10.1 \pm 2.1$ & 0.979 & $0.949-0.992$ \\
\hline & \multirow[t]{2}{*}{ 大腿周径 $(\mathrm{cm})$} & 検者 A & $51.2 \pm 3.0$ & $51.2 \pm 3.0$ & 1. 000 & $0.999-1.000$ \\
\hline & & 検者 B & $51.2 \pm 3.0$ & $51.1 \pm 3.1$ & 0.999 & $0.998-1.000$ \\
\hline & \multirow[t]{2}{*}{ 筋硬度 } & 検者 A & $19.6 \pm 4.0$ & $19.5 \pm 3.7$ & 0.979 & $0.948-0.992$ \\
\hline & & 検者 B & $17.5 \pm 3.7$ & $16.9 \pm 3.2$ & 0.885 & $0.714-0.954$ \\
\hline
\end{tabular}

平均 \pm 標準偏差

表 2 測定值の検者間再現性

\begin{tabular}{|c|c|c|c|c|c|}
\hline & & 検者 A & 検者 B & $\operatorname{ICC}(2,1)$ & $95 \% \mathrm{CI}$ \\
\hline \multicolumn{6}{|c|}{ 男性 } \\
\hline & 筋厚 (mm) & $34.5 \pm 4.2$ & $34.8 \pm 4.6$ & 0.934 & $0.836-0.974$ \\
\hline & 脂肪厚 $(\mathrm{mm})$ & $6.5 \pm 2.6$ & $6.5 \pm 2.7$ & 0.993 & $0.982-0.997$ \\
\hline & 大腿周径 $(\mathrm{cm})$ & $54.1 \pm 4.1$ & $54.1 \pm 4.0$ & 0.997 & $0.992-0.999$ \\
\hline & 筋硬度 & $20.9 \pm 3.2$ & $20.2 \pm 2.9$ & 0.763 & $0.416-0.905$ \\
\hline \multicolumn{6}{|c|}{ 女性 } \\
\hline & 筋厚 (mm) & $30.3 \pm 4.2$ & $30.1 \pm 4.5$ & 0.967 & $0.917-0.987$ \\
\hline & 脂肪厚 (mm) & $9.9 \pm 2.1$ & $10.0 \pm 2.1$ & 0.976 & $0.941-0.991$ \\
\hline & 大腿周径 $(\mathrm{cm})$ & $51.2 \pm 3.0$ & $51.1 \pm 3.0$ & 0.995 & $0.987-0.998$ \\
\hline & 筋硬度 & $19.6 \pm 3.8$ & $17.2 \pm 3.5$ & 0.787 & $0.058-0.933$ \\
\hline
\end{tabular}

平均土標準偏差 
表 3 測定項目間の相関係数

\begin{tabular}{|c|c|c|c|c|c|}
\hline & & 筋厚 & 脂肪厚 & 大腿周径 & 筋硬度 \\
\hline \multicolumn{6}{|c|}{ 男性 } \\
\hline & 脂肪厚 & 0.246 & & & \\
\hline & 大腿周径 & $0.445^{*}$ & $0.663^{*}$ & & \\
\hline & 筋硬度 & -0.357 & -0.149 & 0.038 & \\
\hline & 滕伸展筋力 & 0.156 & 0.112 & $0.536^{*}$ & -0.253 \\
\hline \multicolumn{6}{|c|}{ 女性 } \\
\hline & 脂肪厚 & $0.601^{* *}$ & & & \\
\hline & 大腿周径 & $0.541^{*}$ & $0.881^{* *}$ & & \\
\hline & 筋硬度 & 0.050 & 0.284 & 0.410 & \\
\hline & 膝伸展筋力 & -0.048 & 0.175 & 0.325 & 0.334 \\
\hline
\end{tabular}

相関が認められたのは, 男性の大腿周径 $(r=0.54, p$ <0. 05）のみであった。その他, 男性では大腿周径と 筋厚 $(r=0.445, \mathrm{p}<0.05)$, 脂肪厚 $(\mathrm{r}=0.663, \mathrm{p}<$ $0.05)$ ，女性では大腿周径と筋厚 $(r=0.541, p<0.05)$, 脂肪厚 $(\mathrm{r}=0.881, \mathrm{p}<0.01)$, 筋厚と脂肪厚 $(\mathrm{r}=0.601$, $\mathrm{p}<0.01 ）$ に有意な相関が認められた。また，男女と もに筋硬度と各項目との間に有意な相関は認められな かった。

\section{IV. 考 察}

本研究は, 検者内と検者間の筋厚および脂肪厚, 大 腿周径, 筋硬度測定の再現性を検討し, 最大膝伸展筋 力との相関について検討した。その結果，筋厚，脂肪 厚，大腿周径の測定值には極めて高い再現性が認めら れたが，筋硬度はこれらの項目と比較すると再現性が 劣っていた。また, 男性では膝伸展筋力と大腿周径に 有意な相関が認められたが, 膝伸展筋力と筋厚, 筋硬 度には有意な相関は認められなかった。女性では膝伸 展筋力と有意な相関が認められた項目はなかった。

筋厚㧍よび脂肪厚の測定值の再現性については, 男 女ともに検者内および検者間で「優秀」であり, 筋厚 測定值の妥当性は十分とする先行研究18) 支持するも のであった。一方，筋厚の測定值はプローブの圧迫の 程度により変動すると報告されている 用した超音波画像装置は押圧を定量化でき, 圧を一定 に保つことができるため，極めて高い再現性が得られ たと考えられる。大腿周径の測定值の再現性について は，男女ともに検者内拉よび検者間で「優秀」であっ た。先行研究では, 膝関節裂隙 1 点をランドマークと し, 大腿周径を測定した結果, 検者間再現性が低かっ たと報告している ${ }^{10)}$ 。本研究では上前腸骨棘と滕蓋骨
上縁の 2 点をランドマークとし大腿周径を測定したた め, 高い再現性が得られたものと推察した。

筋硬度の測定值の再現性については, 男女とも検者 内で「普通」から「優秀」, 検者間で「普通」であり, 他の項目と比較すると測定值の再現性が劣っていた。 斎藤は, 筋硬度測定において測定者の習熟度による誤 差や評価者間誤差は避けられないとしている ${ }^{12)}$ 。肥田 らは，測定者が繰り返し練習を行っても測定者間で押 圧量を一定にするのは困難と報告している ${ }^{11)}$ 。した がって, 筋硬度測定は高い習熟度を要するため他の項 目よりも測定值の再現性が劣っていた可能性がある。 膝伸展筋力との相関分析の結果, 男性の大腿周径と の間のみに有意な相関が認められた。これまでにも膝 伸展筋力と大腿周径の間には相関が認められてお $\eta^{6,13,19)}$, これらの先行研究と矛盾しない。一方で, 女性では膝伸展筋力と大腿周径の間に相関はみられな かった。女性では皮下脂肪厚が男性に比べ高く, 特に 大腿部で著しいとされている ${ }^{14)}$ 。四肢周径の測定值に は皮下脂肪などの筋以外の要素も含まれており ${ }^{10}$, 大 腿周径は脂肪厚の影響を受けると指摘されている ${ }^{20}$ 。 本研究では男女ともに大腿周径と脂肪厚に有意な相関 がみられたが，特に女性は強い相関が認められた。し たがって，大腿周径は脂肪厚が強く影響し，女性では 膝伸展筋力と大腿周径に相関がみられなかった可能性 がある。

男女ともに膝伸展筋力と筋厚には有意な相関はみら れず, 筋厚は膝伸展筋力と有意に相関したとする先行 研究 ${ }^{6.8)}$ とは異なった。骨格筋の発揮張力は筋のサイズ のみだけでなく骨格筋内の脂肪や結合組織といった筋 の質も筋力に影響するとされている21)。本研究では筋 内の脂肪や結合組織などの筋の質に関する評価を実施 
していないが，筋厚ではなく筋の質が筋力に影響して いた可能性がある。また, 滕伸展筋力と筋硬度に有意 な相関は認められず，筋力が高い者は筋硬度も高いと 報告している先行研究) とは異なる結果となった。村 木らの先行研究8)では, 超音波弾性計測装置を用い押 圧による筋厚の変位量から筋硬度を算出している。先 行研究と異なり本研究で膝伸展筋力と有意な相関が認 められなかった理由は測定方法の違いによるものかも しれない。

本研究では，超音波画像装置による筋厚および脂肪 厚，大腿周径において検者内・検者間ともに高い再現 性が認められた。ただし, 膝伸展筋力との相関分析で は，男性の大腿周径に有意な相関が認められたのみで， それ以外の項目とは有意な相関は認められなかった。 このことより，臨床的に膝伸展筋力を反映するものと して，男性では大腿周径が有用であること，女性では 大腿周径を評価，解釈する際には脂肪厚について考慮 する必要性が示唆された。

ただし，本研究は健常成人を対象としたものであり， 高齢者で本研究の結果が当てはまるか否か明らかでな い。また, 本研究は筋厚, すなわち筋サイズの測定の みに留まっており，筋の質が膝伸展筋力に関連してい る可能性が考えられる。今後, 高齢者での検証や筋の 質を含めた検討が必要である。

\section{引用文献}

1）甲斐義浩，村田 伸，古後晴基・他：筋音図を用いた大腿 四頭筋の筋機能評価 - 筋電図と筋音図の比較 - 。ルスプ ロモーション理学療法研究, 2012, 1(1)：61-65

2) 村田 潤, 村田 伸, 甲斐義浩：下肢荷重力測定における 荷重量と下肢筋活動の関係. 理学療法科学，2007，22(2) : 195-198.

3）山㟝裕司，横山仁志，青木詩子 - 他：高齢患者の膝伸展筋 力と歩行速度，独歩との関連．総合リハビリテーション， 1998, 26(7) : 689-692.

4）山㠃裕司, 横山仁志, 青木詩子 - 他 : 膝伸展筋力と歩行自 立度の関連－運動器疾患のない高齢患者を対象として，総 合リハビリテーション，2002，30(1)：61-65.

5）河合 恒，大㴊修一，小島基永・他：超音波測定による大 腿前面の筋の硬さと膝伸展筋力の関係. 理学療法科学, 2010, 25(6) : 969-975.

6）甲斐義浩，藤野英己，村田 伸 - 他：下肢周径の測定值と 下肢筋力および筋組織厚の関連．理学療法科学，2008，23 (6) : 785-788.

7）細田多穂，柳澤 健：理学療法ハンドブック 改訂第 4 版 第 1 巻 理学療法の基礎と評価. 協同医書出版, 東京, 2015 , 950

8）村木里志, 福田 修, 福本清剛：筋の厚さ (量) と硬さ (質)
から筋力を推定する方法の開発．健康医科学研究助成論文 集, 2009, 24:126-133

9）福元喜啓，池添冬芽，山田陽介・他：超音波画像診断装置 を用いた骨格筋の量的・質的評価. 理学療法学, 2015, 42 (1) : 65-71.

10）㴊上信夫, 今井公一, 坂田芳明 - 他：周径の信頼性一筋力 と周径の関係一。理学療法学, 1990, 17(3)：242-246.

11）肥田朋子，天野幸代：筋硬度計による生体の硬さ測定－再 現性と妥当性と有用性一。名古屋学院大学論集 人文・自 然科学篇, 2010, $46: 55-61$.

12）斉藤秀之：痛みに関連する生体情報の測定法，理学療法, 2006, 23(1): 99-104.

13）甲斐義浩，藤野英己，村田 伸 ·他：身体組成と上·下肢 筋力および四肢周径に関する研究．理学療法科学，2008, 23(2) : 241-244.

14）古泉一久：筋厚，皮下脂肪厚の分布と身体組成との関係. 城西大学研究年報 自然科学編, 1998, 22：125-133.

15）加藤宗規，山﨑裕司，柊 幸伸・他：ハンドヘルドダイナ モメーターによる等尺性膝伸展筋力の測定－固定用ベルト の使用が検者間再現性に与える影響. 総合リハビリテー ション, 2001, 29(11) : 1047-1050.

16）今井 樹, 潮見泰藏：理学療法研究における “評価の信頼 性”の検査法. 理学療法科学, 2004, 19(3)：261-265.

17）國土将平：相関と回帰。学校保健研究，2017，58(6)：373 $-377$.

18）宮本賢作，田中 聡，田中 愛・他：超音波皮脂厚計を用 いた下肢筋厚測定值の妥当性と筋力・筋量との関連につい て. 形態・機能, 2007, 6 (1) : 27-32.

19）江㟝千恵，村田 伸，宮崎純弥・他：地域在住高齢者の大 腿周径および大腿四頭筋筋厚と大腿四頭筋筋力との関連. 理学療法科学, 2010, 25(5)：673-676

20）岡 英世，市橋則明，吉田正樹・他：MRIによる大腿部 における筋の断面積特性－断面積と周径との関連性一。理 学療法診療, 1995, 6 : 125-129.

21）市橋則明，池添冬芽，福元喜啓 - 他：骨格筋研究一臨床に おけるこれからのチャレンジー。理学療法学, 2010, 37 (8) : 552-556. 